\title{
Urban Rehabilitation, Social Innovation, and New Working Spaces in Lisbon
}

\author{
Sofia Morgado
}

check for

updates

Citation: Morgado, S. Urban Rehabilitation, Social Innovation, and New Working Spaces in Lisbon. Sustainability 2021, 13, 11925. https:// doi.org/10.3390/su132111925

Academic Editor: Harald A. Mieg

Received: 28 September 2021

Accepted: 23 October 2021

Published: 28 October 2021

Publisher's Note: MDPI stays neutral with regard to jurisdictional claims in published maps and institutional affiliations.

Copyright: (C) 2021 by the author. Licensee MDPI, Basel, Switzerland. This article is an open access article distributed under the terms and conditions of the Creative Commons Attribution (CC BY) license (https:/ / creativecommons.org/licenses/by/ $4.0 /)$.
CIAUD, Lisbon School of Architecture, Universidade de Lisboa, 1349-063 Lisboa, Portugal; smorgado@fa.ulisboa.pt

\begin{abstract}
This study brings together three subjects: urban rehabilitation, social innovation, and new working spaces, envisaging an intersectoral viewpoint, focusing on a European city, Lisbon, arguing that the public sector holds the capacity to consistently drive positive achievements in this respect. This study involves analyzing policy, governance, and urban planning documents in force, observation and spatial analysis using open-source databases, and stakeholder interviews. The result is in line with the primary research plea applied to the case study, and conclusions show that public intervention, whenever applied systematically from the city vision to local plans, resorting to close bonds between the sites and the communities in a participatory and collaborative way, may lead to urban rehabilitation and social innovation through the inception and development of new working spaces. The study was designed while researching as a member of COST CA18214 (The Geography of New Working Spaces and the Impact on the Periphery).
\end{abstract}

Keywords: urban rehabilitation; social innovation; new working spaces; municipal urban planning; Lisboa/Lisbon

\section{Introduction}

This study addresses the municipal interplay between urban rehabilitation and regeneration, the location of new working spaces (NWS) [1], and the promotion of social innovation, putting design and urban sustainability at the forefront of the city's strategy. Cities are contextual. Therefore, the study applies to Lisbon, highlighting this specific 21st-century approach to urban planning and design practice.

Following a preliminary study of the location patterns of NWS in Lisbon, it became clear that a new angle could be explored if NWS were observed through the lens of urban rehabilitation and social innovation. Such hypothesis would be confirmed by a systematic review of public policies and urban planning aiming at the development of NWS, at the municipal level, together with funding aimed at Social Innovation projects. The work was developed under the scope of COST CA18214_-The Geography of New Working Spaces and the Impact on the Periphery.

\section{Background}

This study brings together three subjects: urban rehabilitation, social innovation, and new working spaces, envisaging how public sector action can affect all three in a particular city.

Although the correlation between these factors has emerged due to current urban realities, the scientific literature linking them is often lacking. In this case, we aim to look at Lisbon. We wish to bring about particular interventions with a view to social innovation and the creation of new working spaces, taking into account a multilevel perspective (looking at the metropolitan level) whenever possible.

Some authors imply that the creation of new working spaces should germinate from the overall urban planning architecture, which then leads to social innovation. However, 
this article will show that bringing the public institutional realm to the forefront of the debate, as Mieg supports in [2], is crucial.

It is not uncommon to find that the scientific literature tends to be detached from the planning practice due to its specificity. According to Stiftel [3], in some cities it does not even interact with the academic urban and planning realm to work towards general social, economic, and environmental advances.

There is considerable consensus regarding the need for the rehabilitation and repopulation of older city centres [4,5]. Jacobs (1961) [6] and Gehl (1971) [7] introduced the advantages offered by older, traditional districts characterised by diversity and liveability -in a nutshell, this fits the post-modern view of the 15-min city, or even the previous 'vicinity unit' concept. The conditions necessitated by COVID-19, e.g., lockdowns and quarantining, along with the absence of daily commuting, raised the public's awareness of neighbourhoods and the diverse commercial services and amenities they could offer to the public.

Urban rehabilitation and urban regeneration have been addressed in urbanism, specifically in countries with a Romanistic background, where the material quality of space, by design, is synonymous with cultural practices in the construction and the life of a city [8]. However, there are differences between urban rehabilitation and regeneration that are meaningful under the remit of urban planning cultures in terms of the institutional, spatial, urban planning, and design domains [9].

Under this umbrella, urban rehabilitation is promoted publicly, envisaging the material improvement and the functional update and activation of the pre-existing urban fabricbuildings and public spaces_-safeguarding residents and improving their quality of life, i.e., avoiding gentrification [10].

Thus, methodologies, technical teams, partnerships, and participation are vital in this process. This has become a consistent practice in historical centres and suburban areas, where public space qualification and the introduction of functional diversity and jobs is used to promote the public's involvement in the rehabilitation of their own neighbourhoods [10].

In this specific sense, one may argue that urban rehabilitation is intrinsically related to social innovation, when the strategies and planning involved address an urban-social ecosystem driven by different actors seeking to build capacity within the different social layers, through a specific co-creation driver that allows for a positive transformation towards local and interpersonal innovation, bringing effective transformation to the area [11,12].

Furthermore, choosing co-creative environs as drivers of urban fabric rehabilitation and involving local communities in the improvement of their quality of life and wellbeing introduces the third factor that we aim to address, i.e., publicly promoted new working spaces. In the context of this study, international agendas [13], social innovation, and cocreation as a participatory process come together in the design of the public realm [14-16].

Therefore, social innovation emerges as a relevant target for a diverse and inclusive city, strengthening the economy and diversifying the ecosystem of activities-bringing a city back to life. It could be said that social innovation is framed towards a European public policy view, as since the 1980s the regional economic approach has been looking for a way to balance regional disparities. Moulaert (see Chapter 1 (Social Innovation: Institutionally Embedded, Territorially) [17]) argues that, concerning territory, social innovation seeks, among other goals, to transform social relations and the interlinks between space, identity, and culture (what architects and other urban-related professionals address as "place") and to establish governance structures, either regional or local. Domanski [18] refers to social innovation as a critical topic in Horizon 2020, the latest European Union (EU) Framework and, since most of the funding is dependent on EU agreements, goals, and policies, several policies address it specifically.

Conversely, Roberts and Sykes [19] focus on urban regeneration under the AngloSaxon Land Use Management wings, stressing the economic and funding aspects of urban development, resorting to the agency model. In the chapter Evolution, Definition and Purpose, 
Sykes refers to the need for "a comprehensive and integrated vision", i.e., strategy, aiming to provide lasting "economic, physical, social and environmental" improvement (p. 17) [19]. From this line of thought, one finds a direct thread to the importance of economic activities as supporters of jobs and communities and, often, to the involvement of the private sector, such as the real estate market and the international networks of NWS providers.

This study builds on the typology of NWS as considered by COST CA18214-The Geography of New Working Spaces and the Impact on the Periphery-funded by Horizon 2020. This includes (i) collaborative and creative working spaces (coworking spaces and smart work centres); (ii) makerspaces and other technical spaces (fablabs and open workshops); (iii) other new working spaces (hackerspaces, living lab, and corporate labs); (iv) informal new working spaces (coffee shops and libraries) [1].

COST CA18214 provides robust evidence of new working spaces' typology and their location patterns. The location of new working spaces in Lisbon (using open databases such as Google Maps and CoWorker) appear to follow the open real estate market, either as company networks (e.g., international such as Regus) or in older, more traditional districts at a smaller scale, or in more experimental spaces as an option to rent places that have lost their commercial or housing prospects [1,19-25].

Nevertheless, when the intention is to look for new working spaces' role in concrete urban rehabilitation, their capacity to contribute is limited without the will of a public stakeholder, such as a municipality, that has the capacity to draw links between strategy, urban planning, and further implementation and has the leverage to find funding.

Having secured the urban rehabilitation spark, following the waves of free-market choices is an easier way to catalyse urban regeneration, thus following and interacting with a comprehensive set of local urban plans and designs for the city.

Hence, in a welfare state, as in the case study addressed below, the vision of a city usually provides the strategic location for NWSs, considering that:

- Creative and knowledge-based workers share a specific social profile, including a preference for flexible working hours and environments, such as vivid, walkable neighbourhoods. These workers enjoy the diversity of cafes and restaurants, dynamic nightlife, active street life, and cultural events.

- $\quad$ NWS spaces often occupy pre-existing deprived structures, i.e., social-economically peripheral-industrial sites in former urban fringes or current buildings in urban centres-that became inadequate in some way for their previous usage and are thus available.

\section{Materials and Methods}

From an architectural and urbanistic point of view, ethnographic research methods often imply site observations and analysis, especially when seeking to go beyond a morphological approach. This process is phenomenological at its core [25-28].

In urbanism with an architectural and social background, the aesthetic options are erudite, stereotyped, or vernacular. This is what happens in research projects or problem solving-oriented urban design and planning studios and workshops.

In this study, we consider the following: (1) urban practices in Bairro Alto; (2) Urban Design Studios in Mouraria, Marvila, Bairro Alto, as well as international workshops under the aegis of the ISOCARP/Young Planning Professionals; and (3) research spanning the past 20 years addressing the urban transformation of the Lisbon Metropolitan Area. These contribute to our ethnographic perceptions of the places and examples referred to in the study, notably within the historical centre and eastern/oriental territorial units as expressed in the cartographical results. These activities involved local authorities, communities, field trips, observations, and the review of various documents (historical, cartographic, and/or urban planning).

In the conceptualisation of the article, these experiences lay the foundations for how the city of Lisbon was approached. We used (1) literature, especially the contributions from the research network COST CA18214 (The Geography of New Working Spaces and 
the Impact on the Periphery) (see 1. Introduction; The Background); (2) a systematic review of the Lisbon City Council official documents regarding governance and urban planning, such as the analysis of municipal strategy and urban planning documents and interviews with urban planning stakeholders (see 3. Results; 3.1. Governance and Urban Planning in Lisbon: A review) (see (3) spatial analysis and geocoded datasets, official and open source (3. Results; 3.2. Where do the City Vision and the Local Plans Meet?), highlighting the territorial expression of NWS within the Urban Rehabilitation Area of Lisbon (see Figure 1), Administrative and Territorial Units of Management, the current Status of the Urban Development and Detail Plans in Lisbon (see Figures 2 and 3, Table 1), and the concomitancy of the NWS promoted as drivers of social innovation in Detail Urban Rehabilitation plans, the levels of ageing and vulnerability and the concentration of creative industries (see Figure 4 and Table 2).

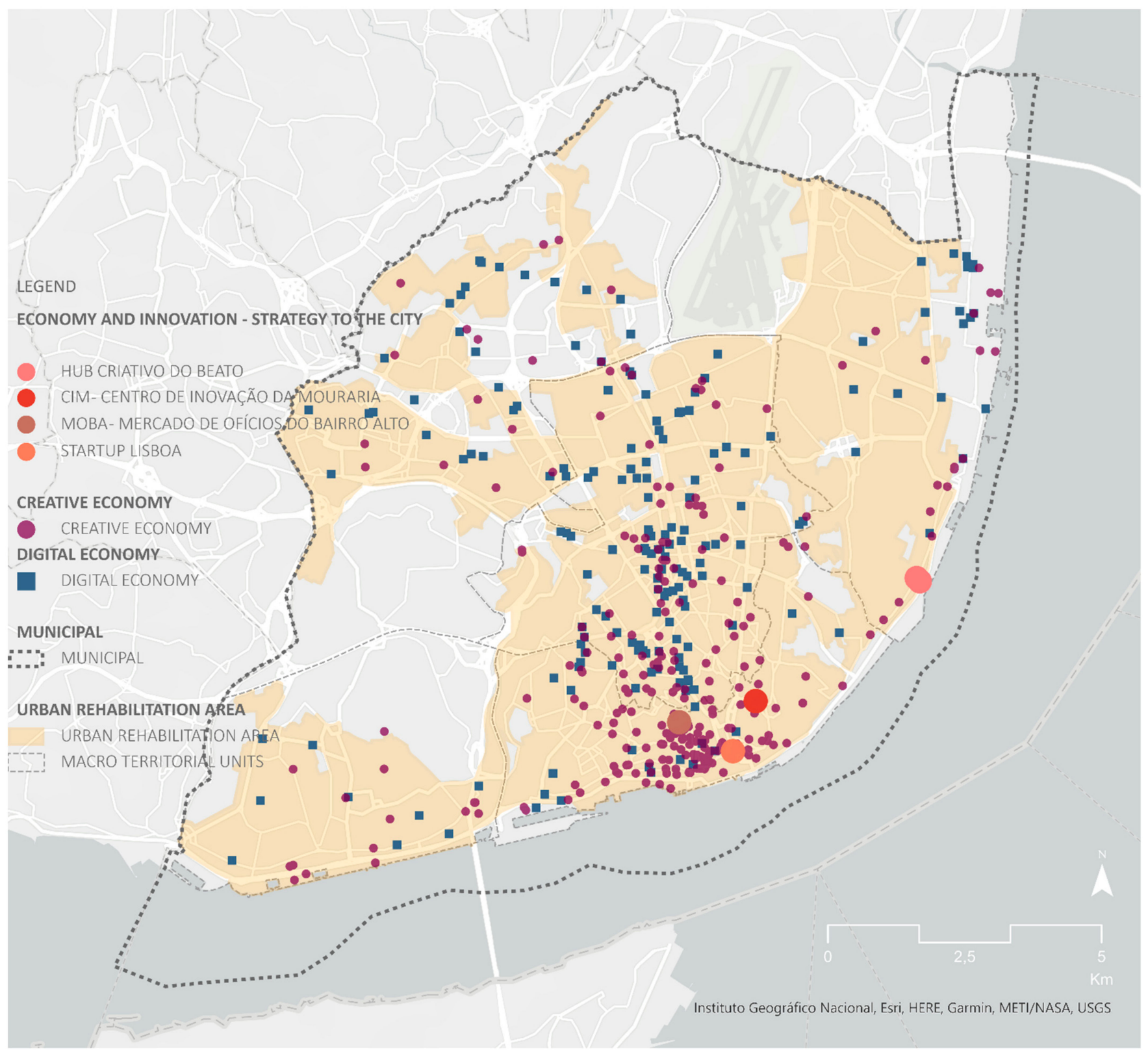

Figure 1. Lisbon rehabilitation area: Creative hubs with a role in urban rehabilitation, creative and digital economy overlap with the urban rehabilitation area, Lisbon City Council. Sources: Adapted from the Lisbon City Council (CML) official open-source dataset (see Back Matter). Basemap source as embedded in figure: Instituto geográfico Nacional, Esri, HERE, Garmin, METI/NASA, UGS. 


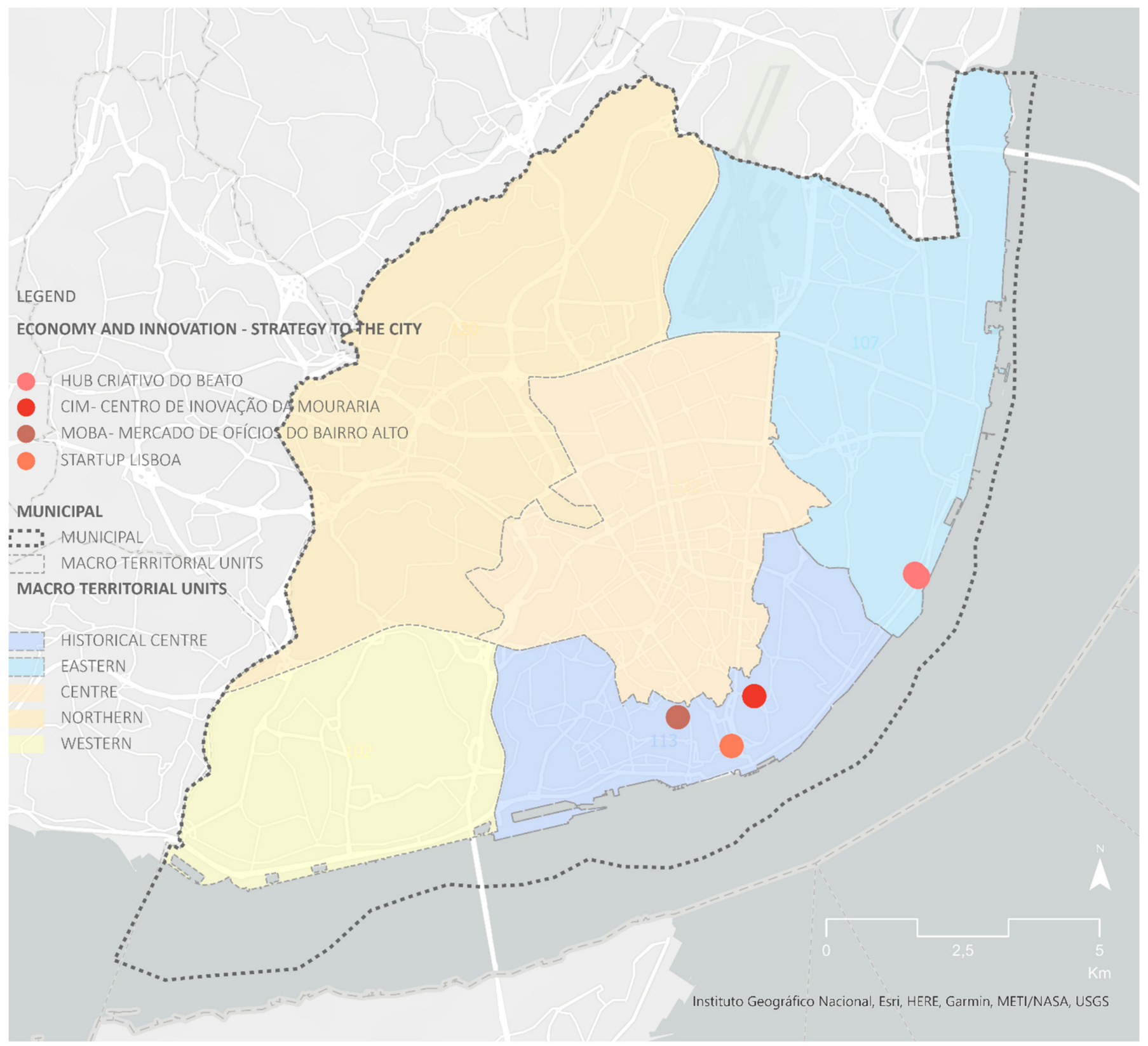

Figure 2. Macro territorial unit boundaries: Creative hubs with a role in urban rehabilitation overlap with the historical centre and eastern/oriental territorial units, Lisbon City Council. Sources: Adapted from the Lisbon City Council (CML) official open-source dataset (see Back Matter). Basemap source as embedded in figure: Instituto geográfico Nacional, Esri, HERE, Garmin, METI/NASA, UGS. 


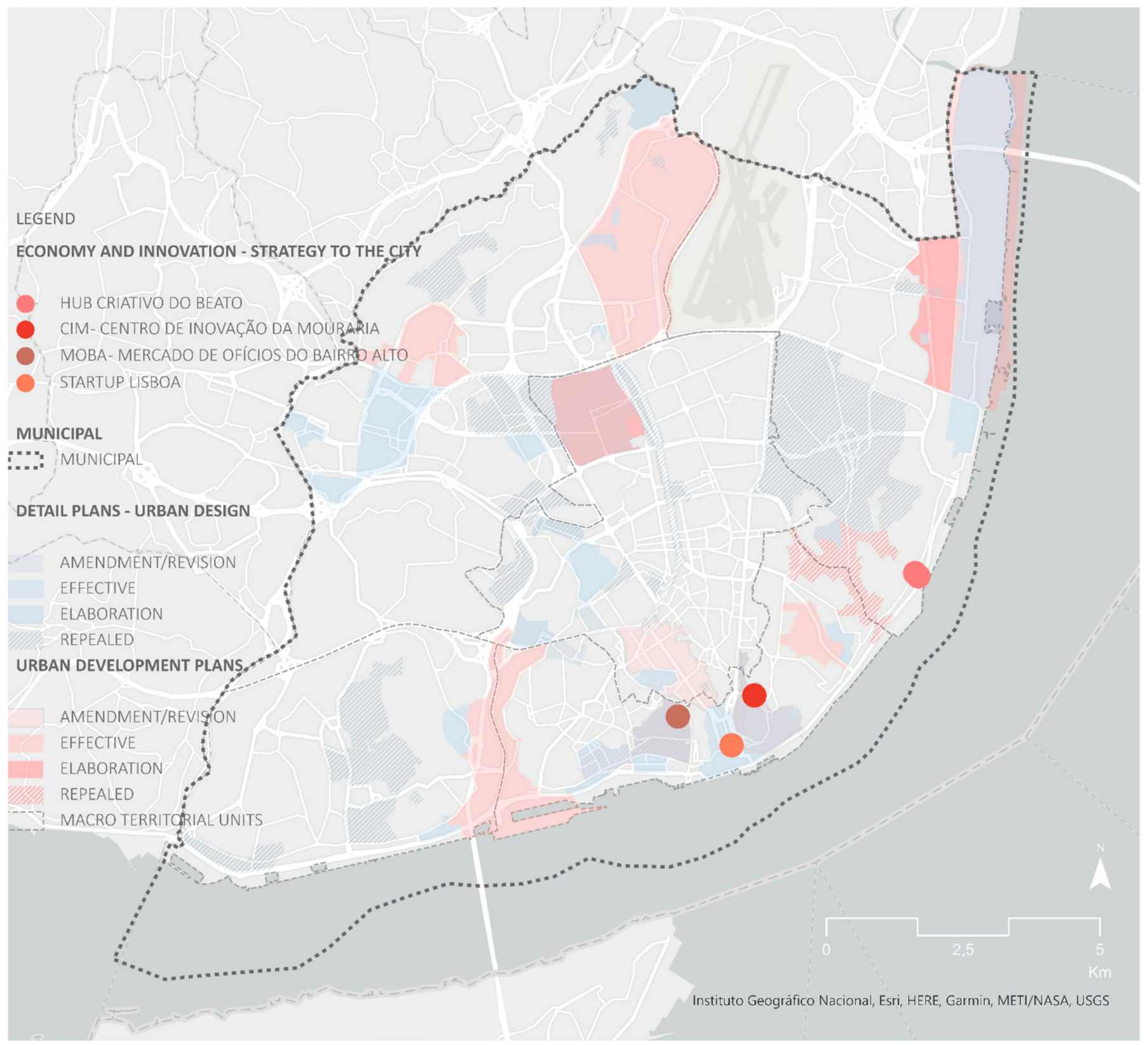

Figure 3. Urban development plans and urban detail plans under various enforcement status: Creative hubs with a role in urban rehabilitation overlap with macro-territorial unit boundaries, by the Lisbon City Council. Sources: Adapted from the Lisbon City Council (CML) official open-source dataset (see Back Matter). Basemap source as embedded in figure: Instituto geográfico Nacional, Esri, HERE, Garmin, METI/NASA, UGS. 
Table 1. City Government strategy and urban planning: Review of major options of plan and the municipal master plan and local urban rehabilitation plan applied to the case study (selection of the relevant material to the study). Sources: Adapted from different official documents and websites of the Lisbon City Council (CML).

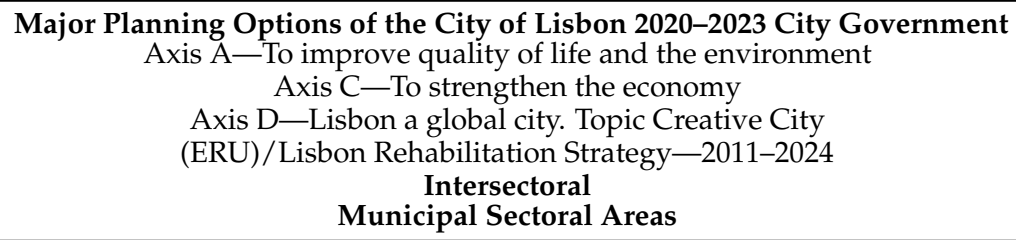

\begin{tabular}{|c|c|c|}
\hline \multirow{2}{*}{ Economy, Innovation, Creative Industries, Culture } & \multirow{2}{*}{ Urban, Heritage, Rehabilitation } & Urbanism \\
\hline & & Urban Planning \\
\hline \multicolumn{3}{|c|}{ Municipal Master Plan_-Urban Rehabilitation Area } \\
\hline Social Innovation New Working Spaces & Urban Rehabilitation Detail Plans & $\begin{array}{l}\text { Public Space Design and } \\
\text { Rehabilitation }\end{array}$ \\
\hline Startup Lisboa & $\begin{array}{l}\text { Heritage Urban Detail Plan Baixa } \\
\text { Pombalina }\end{array}$ & \multirow{3}{*}{$\begin{array}{c}\text { Public Space Design } \\
\text { New Accessibilities to the Castle } \\
\text { Hill (soft mobility including public } \\
\text { free urban lifts) }\end{array}$} \\
\hline $\begin{array}{c}\text { CIM-Mouraria Creative Hub } \\
\text { FabLab Lisboa } \\
\text { H2020 Project HUB IN (Alfama e Mouraria) }\end{array}$ & $\begin{array}{c}\text { Urban Rehabilitation Detailed Plan } \\
\text { Castel Hill }\end{array}$ & \\
\hline $\begin{array}{c}\text { MOBA-Bairro Alto Creative Hub } \\
\text { H2020 Project EU Interreg URBAN M } \\
\text { (Bairro Alto) }\end{array}$ & $\begin{array}{c}\text { Urban Rehabilitation Detailed Plan } \\
\text { Bairro Alto e Bica }\end{array}$ & \\
\hline Beato Creative Hub & $\begin{array}{l}\text { Rehabilitation of a former Factory } \\
\text { Military Site }\end{array}$ & $\begin{array}{c}\text { Waterfront Public Space Design and } \\
\text { Rehabilitation }\end{array}$ \\
\hline
\end{tabular}

Table 2. Population Variation, Census 2011-2021. Portugal NUTS II, Lisbon Metropolitan Area, Lisbon Municipality (preliminary results, July 2021) Source: INE/Statistics Portugal, INE/Statistics Portugal, Preliminary data, Census 2021, available at https:/ / censos.ine.pt/m accessed 29 September 2021.

\begin{tabular}{|c|c|c|c|c|}
\hline \multirow{2}{*}{ NUTS II } & \multicolumn{2}{|c|}{ Population (No. Inhabitants) } & \multicolumn{2}{|c|}{ Variation 2011-2021 } \\
\hline & 2011 & 2021 & No & $\%$ \\
\hline Portugal & $10,562,178$ & $10,347,892$ & $-214,286$ & -2.0 \\
\hline Norte & $3,689,682$ & $3,588,701$ & $-100,981$ & -2.7 \\
\hline Centro & $2,327,755$ & $2,227,912$ & $-99,843$ & -4.3 \\
\hline Lisbon Metropolitan Area & $2,821,876$ & $2,871,133$ & 49,257 & 1.7 \\
\hline Alentejo & 757,302 & 704,934 & $-52,368$ & -6.9 \\
\hline Algarve & 451,006 & 467,495 & 16,489 & 3.7 \\
\hline Azores Autonomous Region & 246,772 & 236,657 & $-10,115$ & -4.1 \\
\hline Madeira Autonomous Region & 267,785 & 251,060 & $-16,725$ & -6.2 \\
\hline \multirow{2}{*}{ Municipality } & \multicolumn{2}{|c|}{ Population (No. Inhabitants) } & \multicolumn{2}{|c|}{ Variation 2011-2021 } \\
\hline & 2011 & 2021 & No & $\%$ \\
\hline Lisboa & 552,700 & 544,851 & -7849 & -1.4 \\
\hline \multirow[t]{2}{*}{ Districts $^{1}$} & \multicolumn{2}{|c|}{ Population (No. Inhabitants) } & \multicolumn{2}{|c|}{ Variation 2011-2021 } \\
\hline & 2011 & 2021 & No & $\%$ \\
\hline Arroios & 31,653 & 33,055 & 1402 & 4.40 \\
\hline Marvila & 35,463 & 37,793 & 2330 & -6.20 \\
\hline Misericórdia & 13,044 & 9645 & -3399 & -26.10 \\
\hline Santa Maria Maior & 12,822 & 9997 & -2825 & -22.00 \\
\hline São Vicente & 15,339 & 13,896 & -1443 & -9.40 \\
\hline
\end{tabular}

${ }^{1}$ Only the districts where the creative hubs headed by the municipality are included. In 2013, administrative reform led to the merging of several old parishes into larger districts. 


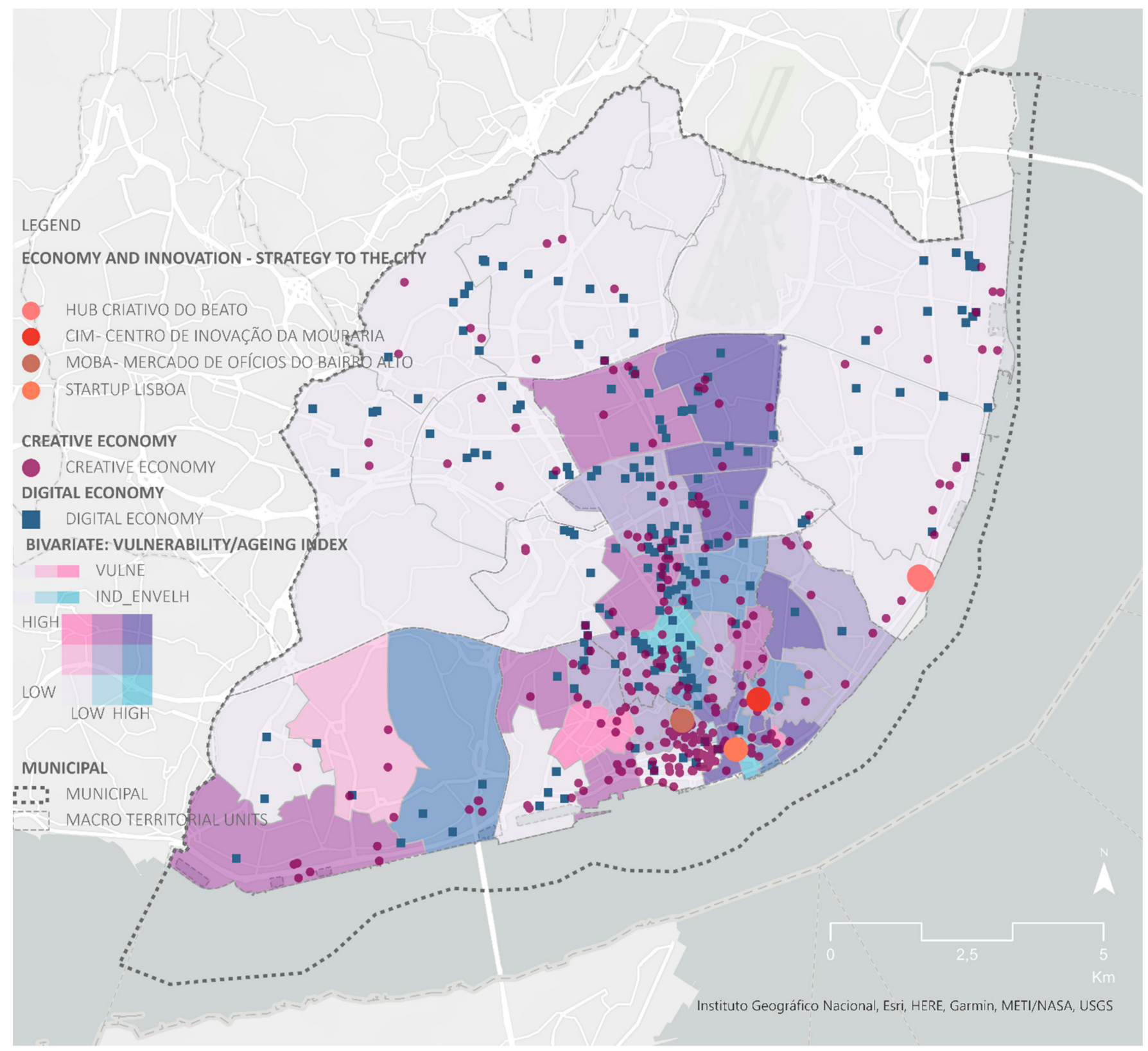

Figure 4. Vulnerability and ageing indexes: Creative hubs in urban rehabilitation, creative and digital economy, overlap bivariate (INE/Statistics Portugal, Census 2011, available at www.ine.pt, 29 September 2021) Sources: Adapted from the Lisbon City Council (CML) official open-source dataset (see Back Matter). Basemap source as embedded in figure: Instituto geográfico Nacional, Esri, HERE, Garmin, METI/NASA, UGS.

\section{Results}

\subsection{Governance and Urban Planning in Lisbon: A Review}

The ties between urban rehabilitation, social innovation, and new working spaces were explored in two fundamental governance documents: the Major Planning Options of the City of Lisbon 2020-2023 (GOP-Grandes Opções do Plano para a Cidade de Lisboa 2020-2023) and the Municipal Master Plan (PDM-Plano Director Municipal) [29,30].

From the urban planning viewpoint, addressing innovation in Lisbon, notably social innovation, requires a comprehensive review of the core strategic and planning documents that address the government of Lisbon at different levels of planning and across sectors of governance. In its institutional organics, the review encompasses the intersectional nature 
of core areas of the council architecture: (i) urbanism (including urban planning and public space design), (ii) economic innovation, and (iii) entrepreneurship.

The Major Planning Options of the City of Lisbon encompasses all areas under the remit of the Municipality of Lisbon and presents the entire strategic vision of Lisbon. The main axes of development include specific goals and measures, including the global budget [28].

Of the five axes of development of the city, three directly address innovation and urban rehabilitation-(i) Axis A: To improve quality of life and the environment; (ii) Axis C: To strengthen the economy, notably by developing innovation networks and promoting partnerships, investment, and trade agreements; (iii) Axis D: Lisbon as a global city fostering the network of spaces for collaborative work and incubation through incentives for urban rehabilitation [30-32] (See Table 1).

The Master Plan for Lisbon (PDM/Plano Director Municipal) provides the territorial expression of the local development strategy, i.e., the major planning options for the city of Lisbon, considering national and regional programmes [30,33,34].

At the governance and strategic municipal level, sectoral areas such as the "economy, innovation, creative industries, and culture", "urban, heritage, and rehabilitation", and "urbanism" (the latter operationalised through different technical departments that include "urban planning" and "public space") share goals defined by the Major Planning Options of the City of Lisbon Axes.

\subsection{Where Do the City Vision and the Local Plans Meet?}

Locally diagnosing, defining a programme, and designing an intervention that responds both to global objectives for the city and a particular neighbourhood deals with a range of current issues directly linked to places and people. At this point, urban planning processes open the door to the need for public participation, especially at the local level, i.e., where the different stakeholders of the city meet the local population [30].

These places and related communities hold certain particularities that technical and deep work about those areas must deal with, notably when they hold heritage value and social frailties, as has become common in the inner fringes of European historical centres, especially if gentrification is to be contained by employing urban rehabilitation.

The Master Plan for Lisbon is the planning document that is meant to find direct threads between the strategy (at the Major Planning Options of the City of Lisbon) and the urban rehabilitation detail plans (see Figure 3).

Lisbon municipality is entirely urban land. Even the larger green areas, such as Monsanto Forest Park, are considered urban. In the 1990s, urban sprawl became a problem and the urban fabric and the built environment became subject to maintenance and reconversion where possible to avoid depopulation and decay in the centre. Most of the municipal area of Lisbon is classified as an urban rehabilitation area (see Figure 1), including most of the area that is characterised by urban occupation. In this respect, urban rehabilitation profiles follow the character of the neighbourhoods and are applicable both to highly regarded areas and less qualified places.

The municipality underwent administrative reform at the national level that merged several tiny old parishes into larger districts with more competencies. Onto this statistical web were lain urban management territorial macro units (see Figure 2), within which the historical centre unit and the eastern/oriental unit were singled out for urban regeneration, the centre for its old fabric, which is extremely difficult to adapt to modern ways of life for the public, heritage value, and topography conditions, and the eastern unit for its former industrial character mixed with pre-existing rural estates, monasteries and palaces that offer riverfront potentialities under current work.

The population differs from neighbourhood to neighbourhood, as the bivariate between the vulnerability index and the ageing index shows (see Figure 4): (1) Mouraria, Baixa, and Bairro alto are peripheral fringes, socially speaking, where an ageing population is marked by poverty, low incomes, and social exclusion in the centre [31]; (2) In Beato, the 
indexes seem to be lower. However, that may result in a dilution of the population density in a larger area, where the urban settlements are post-modern and in large urban units far from the traditional fabric of the centre (except for the waterfront road).

Thus, the social innovation projects sought to mitigate this situation through the implementation of new working spaces (Creation Hubs) as social-spatial drivers of urban rehabilitation in Mouraria, Baixa, Bairro Alto, and Beato. Despite maintaining its position as one of the most populated municipalities in Portugal and the Lisbon Metropolitan Area (LMA), the preliminary Census 2021 results for Lisbon, and specifically in the districts in question shows a clear drop in population (see Figure 4), confirming prior results coming from Census 2011.

The historical centre unit bears the historical neighbourhoods acknowledged as being of historical interest: Mouraria, Baixa and Bairro Alto, each of which is the recipient of a specific urban rehabilitation detail plan and corresponding creative hub as a social innovation driver $[31,32]$ (see Table 2). All these places are central, exceptionally well connected regarding public transportation, and very appealing regarding urban livelihood. Several archeologic layers also condition them, some going back to the Phoenicians and Romans. One can say that this is the heart of the city.

The eastern/oriental unit, marked by the harbour and railway infrastructure and industrial sites, some of them already reconverted or rehabilitated, is the oriental route, part of a nostalgic Lisbon of old ruins, and exquisite palaces. With the development of Parque das Nações into an extremely powerful metropolitan centrality, it gained a new opportunity as a mid-way point between Baixa and the former Expo'98 area (see Table 2) in the area of Beato [31].

\section{Discussion}

It was a crisis that influenced such a small nation globally to discover new cultures and trade routes in the early modern age. The Eurozone crisis 2008 launched Lisbon into a renewed adventure into the realm of creative industries and entrepreneurship. The bailout in 2015, and policies avoiding former austerity measures intensified public and private investment. The well-known hospitality and security offered by the country captured incredible tourism development, raising difficult issues such as, on the one hand, providing capital to invest in the city's rehabilitation, notably in heritage conservation and public space redesign and, on the other, touristification in central districts leading to loss of inhabitants (see Figure 4 and Table 2).

The review of governance and urban planning documents, crisscrossing with spatial and statistics analysis, allows us to observe that the location of creative industries is mainly connected to the historical centre and the urban rehabilitation areas, clustering with the social innovation-led new working spaces. (See Tables 1 and 3, Figure 5).

Table 3. Urban rehabilitation plans and social innovation projects promoted by the Lisbon City Council by date and New Working Spaces Type. Sources: Adapted from different official websites of the Lisbon City Council (CML) and the COST CA18214 typology.

\begin{tabular}{|c|c|c|c|c|c|}
\hline Name & $\begin{array}{c}\text { NWS Type } \\
\text { (COST CA18214) }\end{array}$ & $\begin{array}{l}\text { Main Activities } \\
\text { Promoted by the } \\
\text { City Council } \\
\text { (in Partnership) }\end{array}$ & $\begin{array}{c}\text { Council } \\
\text { Participatory Budget } \\
\text { (OP) and/or } \\
\text { Inception Date }\end{array}$ & $\begin{array}{c}\text { Macro Territorial } \\
\text { Units }\end{array}$ & $\begin{array}{l}\text { Main Urban Detail } \\
\text { Plan/District }\end{array}$ \\
\hline $\begin{array}{l}\text { Start-Up } \\
\text { Lisboa }\end{array}$ & Coworking Space & Incubator & $\begin{array}{l}\text { OP } 2009 \\
2012\end{array}$ & Historical Centre & $\begin{array}{c}\text { Heritage Urban Detail Plan } \\
\text { Baixa Pombalina, } \\
\text { Misericórdia, Santa Maria } \\
\text { Maior, Arroios }\end{array}$ \\
\hline $\begin{array}{c}\text { FabLab Lisboa } \\
\text { [FabLab } \\
\text { Network] }\end{array}$ & Maker Space & $\begin{array}{l}\text { Fabrication } \\
\text { Laboratory }\end{array}$ & 2013 & Historical Centre & \multirow{2}{*}{$\begin{array}{c}\text { Urban Rehabilitation Detail } \\
\text { Plan Castel Hill Santa } \\
\text { Maria Maior, São Vicente } \\
\text { and Arroios, Effective }\end{array}$} \\
\hline $\begin{array}{c}\text { CIM } \\
\text { Mouraria } \\
\text { Creative Hub }\end{array}$ & $\begin{array}{c}\text { Coworking Space, } \\
\text { Maker Space }\end{array}$ & $\begin{array}{l}\text { Creative Industries } \\
\text { Incubator }\end{array}$ & $\begin{array}{l}\text { OP } 2012 \\
2015\end{array}$ & & \\
\hline
\end{tabular}


Table 3. Cont.

\begin{tabular}{|c|c|c|c|c|c|}
\hline Name & $\begin{array}{c}\text { NWS Type } \\
\text { (COST CA18214) }\end{array}$ & $\begin{array}{l}\text { Main Activities } \\
\text { Promoted by the } \\
\text { City Council } \\
\text { (in Partnership) }\end{array}$ & $\begin{array}{c}\text { Council } \\
\text { Participatory Budget } \\
\text { (OP) and/or } \\
\text { Inception Date }\end{array}$ & $\begin{array}{c}\text { Macro Territorial } \\
\text { Units }\end{array}$ & $\begin{array}{l}\text { Main Urban Detail } \\
\text { Plan/District }\end{array}$ \\
\hline $\begin{array}{c}\text { MOBA } \\
\text { Bairro Alto } \\
\text { Creative Hub }\end{array}$ & Maker Space & $\begin{array}{c}\text { Portuguese Arts and } \\
\text { Crafts }\end{array}$ & 2019 & Historical Centre & $\begin{array}{c}\text { Urban Rehabilitation Detail } \\
\text { Plan Bairro Alto e Bica, } \\
\text { Misericórdia, Effective }\end{array}$ \\
\hline $\begin{array}{c}\text { Beato Creative } \\
\text { Hub }\end{array}$ & $\begin{array}{c}\text { Coworking Space } \\
\text { and others }\end{array}$ & $\begin{array}{l}\text { Company Campus } \\
\text { (ongoing) }\end{array}$ & Since 2020 & Eastern/Oriental & $\begin{array}{c}\text { Rehabilitation of a former } \\
\text { Factory Military Site, } \\
\text { Marvila }\end{array}$ \\
\hline
\end{tabular}

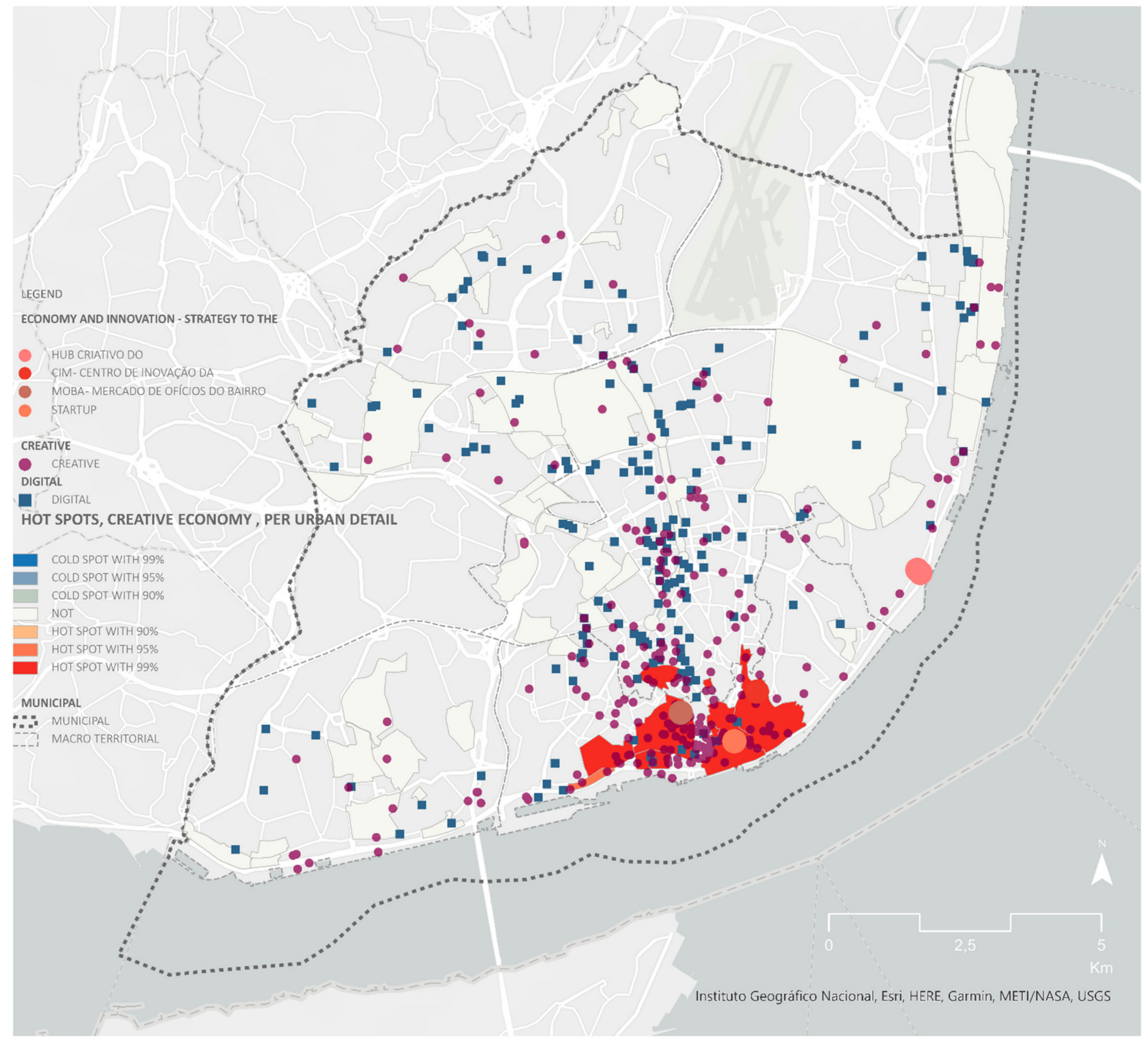

Figure 5. Hot spots analysis applied to urban detail plan polygons-impact of creative hubs and creative economy with a role in urban rehabilitation per urban detail plan in the historical centre territorial unit. Sources: Adapted from the Lisbon City Council (CML) official open-source dataset (see Back Matter). Basemap source as embedded in figure: Instituto geográfico Nacional, Esri, HERE, Garmin, METI/NASA, UGS. 
However, the City of Lisbon made a considerable financial and political investment in developing an innovation and entrepreneurship ecosystem (startups, accelerators, incubators, even unicorns) that would put Lisbon on the international panorama, attracting many young entrepreneurs and creative professionals to the Web Summit since 2016.

The digital economy seems to be located in areas where offices are more significant than the smaller and more scattered "arts and crafts" creative economies in traditional neighbourhoods (See Figure 3).

Urban rehabilitation plans anchor social innovation to new working spaces settled in the available buildings, taking advantage of opportunities offered by outdated or ruined pre-existent structures and the possibility of applying funding to instruments such as the Municipal Participatory Budget (OP/Orçamento Participativo), EU funding mechanisms such as ESFR Funds Creative Europe, H2020 (now Horizon Europe) and EU Interreg, or the Social Innovation Fund [33]. The Social Innovation Fund (FIS) is managed by the Portuguese Development Bank (Banco de Fomento Português, 2020) [34,35]. The Fund aligns with the Agenda 2030 SDG-Sustainable Development Goals and falls under the umbrella of the policy mechanism Portugal Social Innovation (Portugal Inovação Social) with the support of the European Social Fund [33].

Affordable housing for younger families, green strategies, public space design (e.g., introducing soft mobility and increasing pedestrian and cycle lanes) and innovation in buildings that become landmarks allow us to pursue one of the strategic measures of the city by fostering a network of spaces for collaborative work and incubation through incentives for urban rehabilitation.

Measures are also in place to promote the concentration of cultural and creative activities in historic neighbourhoods and spaces with obsolete uses. These actions are vital for urban rehabilitation and the economic and social dynamisation of the areas of this study.

The proximity of the events, the inevitable impacts of COVID-19 and the yet to be discovered strategic reorientation by the new municipal executive team, after Local Elections in September 2021, prevent further discussion.

\section{Conclusions}

Coming to the end of the article, one may well formulate the question implicit in the study's design: Is urban rehabilitation a location factor of NWS and a promoter of social innovation? An unrealistic optimal answer would be positive; however, we can conclude the following:

\subsection{In Lisbon}

- The result lacks the timescale necessary to assess the impacts fully, and more profound research has to be conducted for that specific purpose.

- Even if the cases reported referred to places with underprivileged populations and the embitterment of the whole ecosystem, the improvements sometimes opened the door to highly exclusive real estate projects drawn by the public space quality and diversity ambience, especially in the waterfront area.

- Each intervention sets in motion complex transformations that continually fail to be tamed, at best only reoriented or adjusted, even in the absence of the instability prompted by situations such as COVID-19.

\subsection{From a Broader Perspective}

- Steady governance, a welfare state, social perspectives, funds, and circumstances allow us to invest in and design a particular vision of a city bound together with multilevel and cross-sectoral views.

- Mature urban planning and the design of institutional settings and state of the art technical teams and tools are essential. 
Cities differ by country and political ideology and often have their own unique challenges. Hence, the case presented here is a child of its time. From a global perspective, this is a view from one particular case in Portugal.

Funding: This research received no external funding.

Data Availability Statement: Publicly available datasets were analysed in this study. These data can be found here: https://geodados-cml.hub.arcgis.com/datasets/cb737bd94c134fb68a372de22e383 b7c_11/explore and https://dados.gov.pt/pt/datasets/espacos-e-bairros-criativos/, accessed on 29 September 2021) CM Lisboa 2015, Economia Digital (Digital Economy), ("Dataset of Publicity" The Strategic Actors-Creative Economy—map of Lisbon doesn't represent an exhaustive inventory. It provides data concerning several strategic actors that operate in the city and region according to clusters. Its analysis and selection were performed by Direção Municipal de Economia e Inovação according to online searches on specialised sites and it is constantly being updated and rectified."). CMLisboa 2015, Economia Criativa [Creative Economy], ("Dataset of Publicity" The Strategic ActorsCreative Economy - map of Lisbon does not represent an exhaustive inventory. It provides data concerning several strategic actors that operate in the city and region according to clusters. Its analysis and selection were performed by Direção Municipal de Economia e Inovação according to online searches on specialised sites and it is constantly being updated and rectified."). CMLisboa 2015, Freguesias (Districts) (Serviço de mapa utilizado na aplicação Freguesias de Lisboa.). CMLisboa 2021, Planeamento (Urban Planning) (Map service providing the limits of municipal urban areas and detailed plans.)

Acknowledgments: The author thanks the CA18214-The Geography of New Working Spaces and the Impact on the Periphery (https:/ / www.nmbu.no/en/projects/new-working-spaces, accessed on 22 October 2021) project. The author also thanks Paulo Pais, Architect and Head of the Urban Planning Department, and Susy Silva, Senior Officer of Innovation and Economy, Lisbon City Council, for their insights and contribution to a better understanding of the study's subject.

Conflicts of Interest: The author declares no conflict of interest.

\section{References}

1. Micek, G.; Mariotti, I.; Di Marino, M.; Di Vita, S.; Lange, B.; Paas, T.; Sinitsina, A.; Alfieri, L.; Chebotareva, M.M. Definition and Typologies of the New Working Spaces Deliverable D 1.1. In Internal Working Paper. COST Action CA18214: The Geography of New Working Spaces and Impact on the Periphery (2019-2023); Unpublished Report; European Cooperation in Science and Technology: Milan, Italy, 2020.

2. Mieg, H.A.; Töpfer, K. (Eds.) Institutional and Social Innovation for Sustainable Urban Development; Routledge Studies in Sustainable Development; Routledge: London, UK, 2013; ISBN 978-1-138-78055-2.

3. Stiftel, B. Are We Kidding Ourselves That Research Leads Practice? Urban Plan. 2021, 6, 154-155. [CrossRef]

4. Font, A. (Ed.) L'explosión de la Ciudad: Transformaciones Territoriales en las Regiones Urbanas de la Europa Meridional; Ministerio de Vivienda: Madrid, Spain, 2007; ISBN 978-84-96387-25-6.

5. Keil, R. The Density Dilemma: There Is Always Too Much and Too Little of It. Urban Geogr. 2020, 41, 1284-1293. [CrossRef]

6. Jacobs, J. The Death and Life of Great American Cities; Vintage Books: New York, NY, USA, 1992; ISBN 978-0-679-74195-4.

7. Gehl, J. Life between Buildings: Using Public Space; Island Press: Washington, DC, USA, 2011; ISBN 978-1-59726-827-1.

8. Morgado, S. Lisboa: Um Território Em Formação; Caleidoscópio: Casal de Cambra, Portugal, 2015; ISBN 978-989-658-164-0.

9. The EU Compendium of Spatial Planning Systems and Policies; Regional Development Studies; Office for Official Publications of the European Communities: Luxembourg; Bernan Associates: Lanham, MD, USA, 1997; ISBN 92-827-9752-2.

10. Moura, D.; Guerra, I.; Seixas, J.; Freitas, M.J. A revitalização urbana: Contributos para a definição de um conceito operativo. Cid. Comunidades E Territ. 2006, 15-34. Available online: http://hdl.handle.net/10071/3428 (accessed on 27 September 2021). [CrossRef]

11. Marino, M.D.; Lilius, J.; Lapintie, K. New Forms of Multi-Local Working: Identifying Multi-Locality in Planning as Well as Public and Private Organizations' Strategies in the Helsinki Region. Eur. Plan. Stud. 2018, 26, 2015-2035. [CrossRef]

12. Cabral, V.; Van Winden, W. Coworking: An Analysis of Coworking Strategies for Interaction and Innovation. Int. J. Knowl.-Based Dev. 2016, 7, 357-377. [CrossRef]

13. Nações Unidas. Objetivos de Desenvolvimento Sustentável—Nações Unidas—ONU Portugal (Official Report by the United Nations published in Portuguese). 2015. Available online: https://unric.org/pt/objetivos-de-desenvolvimento-sustentavel/ (accessed on 27 September 2021).

14. Madanipour, A. Temporary Use of Space: Urban Processes between Flexibility, Opportunity and Precarity. Urban Stud. 2018, 55, 1093-1110. [CrossRef] 
15. Llop, C. La regeneració de les trames urbanes: Habitabilitat, activitat, mobilitat i qualitat ambiental. In Transformar la Ciutat Amb la Ciutadania: Criteris i Reflexions per al Pla de Barris de Barcelona; 2017; pp. 93-97. Available online: http://hdl.handle.net/2117/1 07339 (accessed on 29 September 2021).

16. Pultrone, G. Urban Regeneration as an Opportunity of Social Innovation and Creative Planning in Urban Peripheries. TECHNE J. Technol. Archit. Environ. 2017, 14, 139-146. [CrossRef]

17. MacCallum, D.; Moulaert, F.; Hillier, J.; Vicari Haddock, S. (Eds.) Social Innovation and Territorial Development; Ashgate: Farnham, UK; Burlington, VT, USA, 2009; ISBN 978-0-7546-7233-3.

18. Domanski, D.; Howaldt, J.; Kaletka, C. A Comprehensive Concept of Social Innovation and Its Implications for the Local Context-On the Growing Importance of Social Innovation Ecosystems and Infrastructures. Eur. Plan. Stud. 2020, 28, 454-474. [CrossRef]

19. Roberts, P.W.; Sykes, H. (Eds.) Urban Regeneration: A Handbook; SAGE: London, UK; Thousand Oaks, CA, USA, 2000; ISBN 978-0-7619-6716-3.

20. Nakano, D.; Shiach, M.; Koria, M.; Vasques, R.; dos Santos, E.G.; Virani, T. Coworking Spaces in Urban Settings: Prospective Roles? Geoforum 2020, 115, 135-137. [CrossRef]

21. Mariotti, I.; Pacchi, C.; Di Vita, S. Co-Working Spaces in Milan: Location Patterns and Urban Effects. J. Urban Technol. 2017, 24, 47-66. [CrossRef]

22. Lindsay, C.; Pearson, S.; Batty, E.; Cullen, A.M.; Eadson, W. Collaborative Innovation and Activation in Urban Labour Markets Eur. Urban Reg. Stud. 2021, 09697764211003649. [CrossRef]

23. Galdini, R. Temporary Uses in Contemporary Spaces. A European Project in Rome. Cities 2020, 96, 102445. [CrossRef]

24. Capdevila, I. A typology of localized spaces of collaborative innovation. In Entrepreneurial Neighbourhoods-Towards an Understanding of the Economies of Neighbourhoods and Communities; Edward Elgar Publishing: Cheltenham, UK, 2017; ISBN 978-1-78536-724-3.

25. Kubler, G. A Forma do Tempo: Observações sobre a História dos Objectos; Vega: Lisboa, Portugal, 1990; ISBN 978-972-699-236-3.

26. Merleau-Ponty, M. Phénoménologie de la Perception; Tel Gallimard: Paris, France, 2009; ISBN 978-2-07-029337-7.

27. Heidegger, M. Essais et Conferénces; Collection Tel Gallimard: Paris, France, 2001; ISBN 978-2-07-022220-9.

28. Majoor, S.J.H. Coping with Ambiguity: An Urban Megaproject Ethnography. Prog. Plan. 2018, 120, 1-28. [CrossRef]

29. CML/Lisbon City Council. Grandes Opções Do Plano $2020 \mid 2023$ Da Cidade De Lisboa; Câmara Municipal de Lisboa: Lisboa, Portugal, 2019; p. 168.

30. CML/Lisbon City Council. Relatório Da Proposta De Plano do Plano Diretor Municipal De Lisboa (Official Council Report); Câmara Municipal de Lisboa: Lisboa, Portugal, 2012.

31. Pais, P. Interview 1-The Role of the Municipality of Lisbon in Urban Planning and the Promotion of Social Innovation; URBACT: Saint Denis, France, 2021.

32. Silva, S. Interview 2-The Role of the Municipality of Lisbon in the Development of Creative Hubs and Innovation in Lisbon; URBACT: Saint Denis, France, 2021.

33. Portugal Inovação Social I Capacitação Para o Investimento Social, Parcerias Para o Impacto, Títulos de Impacto Social e Fundo Para a Inovação Social. Available online: https://inovacaosocial.portugal2020.pt/en/ (accessed on 24 September 2021).

34. O que é o Fis I FIS-Fundo para a Inovação Social. Available online: https:/ / www.fis.gov.pt/o-que-e-o-fis / (accessed on 24 September 2021).

35. Fomento, B.P. Do Banco Português de Fomento. Available online: https://www.bpfomento.pt/pt/ (accessed on 24 September 2021). 